\title{
FRIENDS OF MAMMOTH AND THE CALIFORNIA EQA
}

The California Environmental Quality Act of 1970 (CEQA) ${ }^{1}$ was the first state law patterned after the National Environmental Policy Act (NEPA). ${ }^{2}$ Signed into law only eight months after the effective date of NEPA, ${ }^{3}$ it quoted verbatim or paralleled closely many of the provisions of the federal Act. ${ }^{4}$ Its key provision was an impact report requirement, based on section $102(2)(\mathrm{C})$ of $\mathrm{NEPA}^{5}$ and relied on by environmentalists to compel serious attention to environmental factors in governmental decisionmaking. ${ }^{6}$ CEQA's impact report requirement

1 Cal. Stats. 1970, ch. 1433, as amended, CAL. Pub. RES. Code $\$ \S 21060-174$ (West -Supp. 1973).

242 U.S.C. $\$ \S 4321-47$ (1970). The similarity between NEPA and CEQA includes passages reproduced almost verbatim. See note 5 infra. This similarity was essential to the court's holding in Friends of Mammoth. See text accompanying notes 11-14 infra.

3 NEPA was signed into law January 1, 1970. CEQA was passed by the California legislature on August 21, 1970 and signed by the Governor on September 18, 1970.

4 See Friends of Mammoth v. Board of Supervisors, 8 Cal. 3d 39, - n.4, 500 P.2d 1360, 1369, 104 Cal. Rptr. 16, 25, modified on denial of rehearing, - Cal. 3d -, 502 P.2d 1049, 104 Cal. Rptr. 761 (1972). For an example of the similarity between NEPA and CEQA, see note 5 infra.

5 The similarity between the two acts is evident from a comparative reading of the sections requiring impact reports:

The Congress authorizes and directs that, to the fullest extent possible . . all agencies of the Federal Government shall-

(C) include in every recommendation or report on proposals for legislation and other major Federal actions significantly affecting the quality of the human environment, a detailed statement by the responsible official on-

(i) the environmental impact of the proposed action,

(ii) any adverse environmental effects which cannot be avoided should

the proposal be implemented,

(iii) alternatives to the proposed action,

(iv) the relationship between local short-term uses of man's environment and the maintenance and enhancement of long-term productivity, and

(v) any irreversible and irretrievable commitments of resources which would be involved in the proposed action should it be implemented.

42 U.S.C. \& $4332(2)$ (C) (1970).

All state agencies, boards, and commissions shall include in any report on any project they propose to carry out which could have a significant effect on the environment of the state, a detailed statement by the responsible state official setting forth the following:

(a) The environmental impact of the proposed action.

(b) Any adverse environmental effects which cannot be avoided if the proposal is implemented.

(c) Mitigation measures proposed to minimize the impact.

(d) Alternatives to the proposed action.

(e) The relationship between local short-term uses of man's environment and the maintenance and enhancement of long-term productivity.

(f) Any irreversible environmental changes which would be involved in the proposed action should it be implemented.

Cal. Stats. 1970, ch. 1433, at 2781-82, as amended, CAx. Pub. Res. Code $\$ 21100$ (West Supp. 1973).

6 See, e.g., Keith v. Volpe, 352 F. Supp. 1324 (C.D. Cal. 1972) ; Environmental Defense Fund, Inc. v. Coastside County Water Dist., 27 Cal. App. 695, 104 Cal. Rptr. 197 (1972). For accounts of other cases filed under.CEQA, see 3 BNA ENv. REP., CuRRENT DEV. $457,595,801$ (1972). 
was even more broadly cast in some respects than section $102(2)(C){ }^{7}$ This expansive version of section $102(2)$ (C) was to be applied to the regulatory system of a state, vastly more diverse, pervasive and intimate than the federal administrative scheme into which section 102 (2) (C) intruded so shortly before. It seemed inevitable from the outset, then, that CEQA would have a profound impact on the course of government and indirectly on the lives of private citizens in California. The full dimensions of this impact were not appreciated, however, until the decision in Friends of Mammoth v. Board of Supervisors. ${ }^{8}$

In Friends of Mammoth, the California Supreme Court held that CEQA required a county planning commission to prepare an environmental impact report prior to approving a conditional use permit for a private developer. The decision raised the specter of near-total paralysis of the state's present and future regulatory activities, as agencies and municipalities wondered how to obtain the staff, money and expertise necessary to meet the requirements it imposed, and to cope with the inevitable delays. The California Legislature responded quickly, however, with comprehensive amendments to CEQA which went into effect only ten weeks after the initial decision. ${ }^{9}$ By the combined efforts of court and legislature, California now possesses the most advanced and least ambiguous statute in the nation declaratory of government policy and procedure respecting the environment. Its significance is national in scope, because many of the problems California has had to deal with can occur, and have occurred, in connection with similar legislation elsewhere. ${ }^{10}$ States which are considering enacting environmental statutes, or amending existing laws, would do well to learn from California's experience. This Comment will discuss the background, nature and future prospects of CEQA, and the ways in which it has solved-or perpetuated-problems attending the impact report requirement.

\section{Friends of Mammoth}

A private developer had obtained a conditional use permit to build a complex of condominiums and shops on five and one-half acres of Mono County, a sparsely populated area described by the court as "primarily mountainous and open range land .... one of the na-

7 While NEPA requires reports only on "major Federal actions significantly affecting" the environment, CEQA applies to any project which may have a significant effect. See note 5a supra. For the significance that should be attributed to CEQA's substitution of "project" for "actions," see text following note 17 infra. The amendments retain the relevant language of the original section, but place other restrictions on the requirement. See notes 25-50 infra \& accompanying text.

88 Cal. 3d 39, 500 P.2d 1360, 104 Cal. Rptr. 16, modified on denial of rehearing, Cal. 3d -, 502 P.2d 1049, 104 Cal. Rptr. 761 (1972).

8 CAL. PUB. RES. CODE $\S \S 21060-174$ (West Supp. 1973).

10 At least 13 American jurisdictions have impact statement requirements similar to those found in NEPA. See note 78 infra \& accompanying text. 
tion's most spectacularly beautiful and comparatively unspoiled treasures."11 The development was opposed by local landowners, who claimed that it would create severe problems of water supply, sewage disposal, snow removal, police protection and general diminution of open space. Alleging noncompliance with CEQA in the failure of the planning commission that issued the use permit to prepare an impact statement, these landowners sought a writ of administrative mandamus, attacking the validity of the permit. The superior court denied the writ and plaintiffs appealed.

In holding that an impact report should have been prepared, the supreme court was required to find both that the legislature intended CEQA to apply to regulatory, as well as proprietary government action, and that the language of the statute was adequate to achieve that purpose. On the first question, the Act's sweeping declarations of legislative intent aided the court. ${ }^{12}$ In resolving the second issue, the court was persuaded by the failure of the legislature to expressly exclude private action under state license, coupled with references to "agencies which regulate [private] activities"13 and to the environmental responsibility of "every citizen."14 Accordingly, the court found that CEQA was intended to apply to the use permit in question.

In determining that the statute would bear the proffered construction, the court was confronted with the arguably limited applicability of the impact report requirement for "projects they [local govern-

118 Cal. 3d at $\rightarrow, 500$ P.2d at.1364, 104 Cal. Rptr. at 20.

12 The Legislature finds and declares as follows:

(e) Every citizen has a responsibility to contribute to the preservation and enhancement of the environment.

(f) The interrelationship of policies and practices in the management of natural resources and waste disposal requires systematic and concerted efforts by public and private interests to enhance environmental quality and to control environmental pollution.

(g) It is the intent of the Legislature that all agencies of the state government which regulate activities of private individuals, corporations, and public agencies which are found to affect the quality of the environment, shall regulate such activities so that major consideration is given to preventing environmental damage.

CAL. Pub. Res. Code $\S 21100$ (West Supp. 1973).

The Legislature further finds and declares that it is the policy of the state to:

(d) Ensure that the long-term protection of the environment shall be the guiding criterion in public decisions.

(f) Require governmental agencies at all levels to develop standards and procedures necessary to protect environmental quality.

(g) Require governmental agencies at all levels to consider qualitative factors as well as economic and technical factors and long-term benefits and costs, in addition to short-term benefits and costs and to consider alternatives to proposed actions affecting the environment.

Id. $\S 21001$. court).

138 Cal. 3d at -, 500 P.2d at 1366, 104 Cal. Rptr. at 22 (emphasis supplied by the

$14 I d$. 
mental agencies] intend to carry out."15 To meet this contention, the court had to first define what a "project" is. Since CEQA provided no guide for definition, the court referred to interim guidelines promulgated under NEPA by the Council on Environmental Quality (CEQ) ${ }^{16}$ prior to CEQA's adoption. ${ }^{17}$ Although NEPA's impact statement requirement applies to certain "actions"-arguably a broader classification than "projects"-the CEQ guidelines designated "projects and continuing activities" as a subcategory of "actions." It is under this subcategory that a "Federal lease, permit, license, certificate or other entitlement for use" is subject to the act. ${ }^{18}$ The grant of a permit, as in the instant case, was a project under the Council's guidelines and, because of the close relationship of the California Act to the federal Act, under CEQA.

The court also rejected the defendants' argument that the words "they intend to carry out" foreclosed application of CEQA to private actions. Restricting the scope of the report provisions to include only public works would defeat the purposes of the Act, particularly in less populous counties, such as Mono, which are unlikely to have the resources to undertake major projects on their own. The phrase was, therefore, interpreted as a requirement that "government must have some minimal link with the activity."119

On denying rehearing, the supreme court clarified and limited its holding. It noted that CEQA required reports to be prepared only for projects that could "have a significant effect on the environment," a fact that had gone unnoticed in the earlier opinion. The court expressed its belief that this limitation, ${ }^{21}$ along with the typically short

15 Cal. Stats. 1970, ch. 1433 , at 2783 , as amended, CAL. PUB. RES. CODE $\S 21151$ (West Supp. 1973):

[L]ocal government agencies [which do not have an officially adopted conservation element of a general plan] shall make an environmental impact report on any project they intend to carry out which may have a significant effect on the environment and shall submit it to the appropriate local planning agency as part of the report required by Section 65402 of the Government Code.

$16 \mathrm{CEQ}$, Statements on Proposed Federal Actions Affecting the Environment-Interim Guidelines, 35 Fed. Reg. 7390 (1970) [hereinafter cited as CEQ Interim Guidelines], superseded by $\mathrm{CEQ}$, Statements on Proposed Federal Actions Affecting the Environment-Guidelines, 36 Fed. Reg. 7723 (1971) [hereinafter cited as CEQ Guidelines]. 17 The guidelines were relevant legislative history because of the close relationship between the two statutes. See text accompanying notes 1-6 supra.

$18 \mathrm{CEQ}$ Interim Guidelines, supra note 16, at 7391.

198 Cal. 3d at —, 500 P.2d at 1370, 104 Cal. Rptr. at 26.

20 See note 5 supra.

21 [C]ommon sense tells us that the majority of private projects for which a government permit or similar entitlement is necessary are minor in scopee.g., relating only to the construction, improvement, or operation of an individual dwelling or small business-and hence, in the absence of unusual circumstances, have little or no effect on the public environment. Such projects, accordingly, may be approved exactly as before the enactment of the EQA.

- Cal. 3d at -, 502 P.2d at 1065, 104 Cal. Rptr. at 777. The court cautioned, however, against abuse of the "significant effect" qualification to avoid preparation of impact reports. Id. 
statutes of limitations applicable to challenging administrative action, ${ }^{22}$ would result in relatively little dislocation of past and present decisions. Accordingly, it refused to apply its holding prospectively only, or to postpone its effective date.

\section{The CEQA Amendments}

The legislative response to Friends of Mammoth was swift. On December 5, the legislature adopted amendments to CEQA, to go into effect immediately. ${ }^{23}$ In general, the amendments ratified the court's holding, even going so far as to state that certain key provisions were intended "only to declare and to clarify existing law."24 Although prepared in relative haste, these changes and additions show careful drafting and reflect considered response to problems raised by cases. arising under NEPA, as well as those growing out of Friends of Mammoth. Review of the new provisions is instructive, particularly in the light of continuing controversy over the construction of the federal Act.

\section{A. Statutory Definitions}

Section 1 of the amendments provides exclusive ${ }^{25}$ definitions of the principal terms used in the Act. Here we find a statutory definition of the "environment," NEPA. By defining environment as "physical conditions" the amendments do little violence to traditional notions of appropriate environmental concerns, while foreclosing any attempts to transform limited judicial scrutiny of compliance with statutory requirements into a general power of administrative review. NEPA's use of the term "human environment"27 has led courts to demand impact statements based on unorthodox concepts of "environmental" issues: "environment," under some federal decisions, has cut loose from its antecedents -the once-fashionable "ecology" and the antediluvian "conservation" -and acquired sociological overtones. ${ }^{28}$ It can be assumed that the

22 The court noted that there was a 30-day statute of limitations in Mono County for challenging a Board of Supervisors' decision, which the court considered typical. 8 Cal. 3d at -, 502 P.2d at 1066, 104 Cal. Rptr. at 778.

23 Cax. Pub. Res. Code $\S \S 21060-174$ (West Supp. 1973), amending Cal. Stats. 1970, ch. 1433. The law was passed under the urgency provision of the California Constitution, requiring a two-thirds majority in each house for an act to take immediate effect. CAI. Const. art. 4, \& 8 (West Supp. 1973).

24 Cal. Stats. 1972, ch. 1154, § 17, 1972 West's Cal. Leg. Serv. at 2647. The provisions were those adding definitions of terms used in the Act. Id. $\$ 1$, at 2639 ; see notes 25-32 infra \& accompanying text. It is possible, of course, that the quoted language was also designed to ward off further judicial expansion of CEQA based on the amendments.

25 "Unless the context otherwise requires, the definitions in this chapter govern the construction of this division." CAL. PUB. RES. CODE $§ 21060$ (West. Supp. 1973), amending Cal. Stats. 1970, ch. 1433.

$26 I d$.

27 NEPA $\S 102(2)$ (C), 42 U.S.C. $\S 4332$ (2)(C) (1970), quoted in note 5 supra. 28 See, e.g., Hanly v. Mitchell, 460 F.2d 640, 647 (2d Cir.), cert. denied, 409 U.S. 
legislature was aware of this possible construction and made a conscious decision to avoid it.

Also significant is the definition of an environmental impact report as an "informational document." ${ }^{29}$ Together with the amendments' limitations on judicial review, ${ }^{30}$ this denial of substantive controlling weight to the report should place appropriate limits to private suits seeking to delay or prevent projects by using the report requirement. Such actions are essential to assure the proper degree of environmental concern in government decisions, but they are also subject to abuse by those seeking to substitute their judgment-or a court's-for that of responsible agencies. ${ }^{31}$

The legislature adopted the supreme court's construction in its definition of "project."32 At the same time it exempted purely ministerial acts from the class of projects to which CEQA applies. ${ }^{33}$ This limitation reflects the most significant policy behind the preparation of impact statements: to assure that environmental issues will be given their due weight in decisionmaking. The ideal impact statement serves this purpose by placing all relevant environmental facts before the body responsible for making decisions. An impact report would be of no value to the official who lacks discretionary powers-whose duty, in other words, is mandated by statute or regulation according to clear objective criteria. An example of such an official is the civil servant responsible for processing hunting license applications. Although it might affect his perception of issues involved, preparing an impact report would not in any way alter his behavior; for if a particular application complies with formal requirements, the license must issue.

The distinction drawn by the amendments between discretionary and ministerial acts places the responsibilty for report preparation at the level of government where authority exists to act on the report. The amendments thus implicitly recognize that projects which are ministerial at one level may be discretionary at a higher level. To expand

990 (1972), after remand, Hanly v. Kleindienst, 471 F.2d 823 (2d Cir. 1972), cert. denied, 93 S. Ct. 2290 (1973); Goose Hollow Foothills League v. Romney, 334 F. Supp. 877 (D. Ore. 1971). 1433.

29 Cal. Pub. Res. Code $\S 21061$ (West Supp. 1973), amending Cal. Stats. 1970, ch.

30 See notes 64-76 infra \& accompanying text.

31 This is not to suggest that an impact report can never be the basis for overturning administrative action; merely that judicial restraint is mandated. See notes $65-77$ infra \& accompanying text.

32 'Project' means the following:

(a) Activities directly undertaken by any public agency.

(b) Activities undertaken by a person which are supported in whole or in part through contracts, grants, subsidies, loans, or other forms of assistance from one or more public agencies.

(c) Activities involving the issuance to a person of a lease, permit, license, certificate, or other entitlement for use by one or more public agencies.

CAL. Pub. Res. Code $\$ 21065$ (West Supp. 1973), amending Cal. Stats. 1970, ch. 1433.

33 The amendments draw a distinction between discretionary projects-specifically including zoning decisions-and ministerial projects. Id. § 21080. 
on the hunting license example above: a wildlife agency may have power to set quotas for hunting licenses without being able to deny individual licenses short of that quota. Restricting the report requirement to discretionary projects also avoids duplication at successive levels of government, and assures that statements will be prepared at the point in the hierarchy most likely to have the necessary personnel, funding, and expertise for thorough and intelligent study. Finally, it may also reflect a refinement of the requirements, developed in federal law, that projects which may be individually insignificant, but which together form an integral project with a significant impact, be considered in the aggregate for impact report purposes. ${ }^{3 \pm}$

In administering CEQA, however, the California courts should avoid the same tortured distinctions between "discretionary" and "ministerial" acts that have plagued the law of governmental immunity and torts. The distinction here should be regarded merely as an administrative housekeeping provision: ministerial functions should be only those in which an officer or agency serves merely as a conduit, with no legal power to alter the flow.

\section{B. The Role of the Resources Agency}

The relevant class of projects is narrowed still further by the new section 21084, which gives the Secretary of the Resources Agency power to make categorical exceptions to CEQA's coverage. ${ }^{35}$ Classes of projects may be exempted if the Secretary finds they "do not have a significant effect on the environment."36 However, the Secretary is not totally free to exempt classes of projects from the report requirement because a finding of significant effect is required by section 21083 (b) whenever "[ $t]$ he possible effects of a project are individually limited but cumulatively considerable." If these two sections are read together, the most plausible construction is that only classes of projects may be exempted that, considered as a whole, have no significant environmental effect. A second, more refined reading is also consistent with the statutory language and purpose. In the "aggregate impact" situation, individual actions could be exempted as a class; that is, no impact report would be required for each such act. The class itself, however, would not be exempt. The responsible agency would be required to report on the total impact of its actions, as well as on any action it takes with respect to the whole class. To return to the previous example: no impact report would be required for the issuance of a single hunting license, even if issuance were discretionary. But the agency would have to report on the cumulative effect of its licensing, as well as that of periodically established quotas.

\footnotetext{
34 See CEQ Guidelines, supra note 16, at 7724 (1971).

35 CaL. Pub. Res. Code $\S 21084$ (West Supp. 1973), amending Cal. Stats. 1970, ch.
} 1433. 
In implementing section 21084, the Resources Agency originally proposed exemptions to the impact report requirement which closely paralleled those suggested by the court in Friends of Mammoth: ${ }^{37}$ repairs, maintenance or minor alteration of existing structures and construction of individual, detatched, single- and double-family homes. ${ }^{38}$ A subsequent revision has extended the exemption to three- and fourfamily units. ${ }^{39}$ There is little danger that these exemptions will be abused, since the statute specifically applies to such aggregations of individual building decisions as zoning ordinances, variances, and approval of subdivision maps. ${ }^{40}$ Even in the absence of specific requirements, the letter and spirit of CEQA and the amendments require reporting in those and other cases where individual exempt activities combine to form an environmentally significant whole.

A more debatable exception appears in the Resources Agency's second draft of the proposed guidelines. No report would be required on agency projects to maintain, restore or enhance a natural resource or the environment. ${ }^{41}$ The difficulty with this standard is that it appears to rely on the intent of the agency, rather than an impartial assessment of a proposed project's real impact. Unless an agency prepares the equivalent of an impact report for internal use, it cannot be certain that the desired, result will be achieved. If such a report is prepared, there is little reason for failing to make it public. The only real effect to be anticipated from this guideline is the encouragement of irresponsible agency action in carrying out projects without adequate study of possible consequences. The guideline may also be invalid under the language of CEQA. The Act requires an impact report whenever a potential effect is significant; there is no further requirement that the effect be adverse. ${ }^{42} \mathrm{CEQA}$ also cautions against seeking short-term environmental ends to the detriment of long-term goals; the proposed guideline makes no allowance for a possible conflict between the two.

37 Note 21 supra.

38 BNA Env. Rep., Current Dev. 1068 (1973).

39 L.A. Times, Feb. 18, 1973, § 1, at 3, col. 5. 1433.

40 Car. Pub. Res. Code $\S 21080$ (West Supp. 1973), amending Cal. Stats. 1970, ch.

41 L.A. Times, Feb. 18, 1973, § 1, at 3, col. 5 .

$42 \mathrm{It}$ is necessary to note that not only are all significant effects not adverse, but also all adverse effects are not significant. The statute requires a finding of significant effect whenever a project "has the potential to degrade the quality of the environment ...." CAL. PuB. Res. CODE \& 21083(a) (West Supp. 1973), amending Cal. Stats. 1970, ch. 1433 , at 2782. Although this phrase threatens to swallow up the exception for projects which will not have significant impacts, courts can be expected to read CEQA as a whole and avoid such a misconstruction. Degradation must mean more than any adverse impact; the term connotes important and permanent deterioration and should be read in that way.

As to whether effects which are not adverse can be significant in the federal context, see CEQ, Preparation of Environmental Impact Statements-Proposed Guidelines, 38 Fed. Reg. 10856, 10857 (1973). These most recent proposed guidelines suggest that significant effects can include actions with both beneficial and detrimental effects even if on balance the effects are beneficial. 
The power of the State Planning Office to propose, and the Resources Agency to adopt, categorical exemptions to the impact statement requirement, based on a finding of insignificant environmental effect, is only one facet of their overall responsibility under the amendments to provide guidelines for the preparation of the reports. Section 21083 of the amendments ${ }^{43}$ directs that they provide guidelines which will assist agencies in making the threshold determination that a proposed project may have a significant environmental effect. However, the legislature itself provided only minimal guidance to the Resources Agency in defining what constitutes significant impact, a problem with which the federal courts have had to grapple. ${ }^{44}$ The new section provides guidance only to the extent of establishing a statutory ceiling on environmental effects which may be deemed insignificant; that is, it mandates a finding of significant effect in broadly defined situations. ${ }^{45}$ These situations closely parallel those requiring an impact report under the CEQ guidelines ${ }^{48}$ cited by the court in Friends of Mammoth.

The failure of the legislature to more specifically define significant impact may be compensated for in part by the demonstrated willingness of the Resources Agency to adopt concrete guidelines-at least as to the types of projects covered. ${ }^{47}$ Besides exempting certain classes of building permits, ${ }^{48}$ the Resources Agency's proposed guidelines identify particular subjects of environmental concern. They are frequently qualitative rather than quantitative in nature, enumerating specific classes of actions without attempting to give content to the

43 CaL. Pus. Res. Code $\S 21083$ (West Supp. 1973), amending Cal. Stats. 1970, ch. 1433 , at 2782 .

44 See, e.g., Hanly v. Kleindienst, 471 F.2d 823 (2d Cir. 1972), cert. denied, 93 S. Ct. 2290 (1973); Natural Resources Defense Council v. Grant, 341 F. Supp. 356, 367 (E.D.N.C. 1972).

45 Guidelines [developed by the Office of Planning and Research] shall specifically include criteria for public agencies to follow in determining whether or not a proposed project may have a "significant effect on the environment." Such criteria shall require a finding of "significant effect on the environment" if any of the following conditions exist:

(a) A proposed project has the potential to degrade the quality of the environment, curtail the range of the environment, or to achieve short-term, to the disadvantage of long-term, enviromental goals;

(b) The possible effects of a project are individually limited but cumulatively considerable;

(c) The environmental effects of a project will cause substantial adverse effects on human beings, either directly or indirectly.

Cat. PUb. Res. Code \& 21083 (West Supp. 1973), amending Cal. Stats. 1970, ch. 1433, at 2782 .

46 CEQ Guidelines, supra note 16 , at 7724-25.

47 For a statute more clearly committed to this classificatory approach, see IND. ANN. STAT. $\S 35-5303$ (c) (v) (Supp. 1972). It may be that an exhaustive list of projects deemed to require impact reports will be more useful, in the ordinary run of regulatory activity, than any attempt to refine the content of the "substantial" limitation to a workable standard of universal application. The latter approach, more satisfactory to courts and theoreticians, has the practical advantage of providing a guideline for the unique case and the case of first impression.

48 Text accompanying notes $37-41$ supra. 
"substantial" limitation. There is a suggestion of particular concern about two subjects: increased traffic and threats to rare or endangered species; impact reports are required on any projects affecting these areas.

One of the originally proposed guidelines adopted a secondary index of environmental impact, similar to one that has been applied under NEPA: ${ }^{48}$ a report would have been prepared on a private building project that could cause serious adverse public reaction based on environmental issues. ${ }^{50} \mathrm{~A}$ strong reaction to a project by environmentalists is a good indication that it may adversely affect the environment. In addition, preparation of reports on major projects-those most likely to engender opposition-could avert undue delay by removing at least one ground on which a suit might be brought to forestall construction. At the same time, this proposed guideline manifested concern that the impact report procedure not be made a vehicle for expressing general disagreement with agency policy. No matter how strong the public reaction, no report would have been required unless the opposition had been based on environmental concerns. Nevertheless, the revised guidelines omit popular opposition altogether as an indication of substantial impact. This may have been done out of concern over potential abuse, or because of the obvious difficulty involved in assessing public reaction to a project in advance. For the reasons just discussed, the original provision was a sensible measure, and should have been retained.

\section{Preparing the Impact Statement}

CEQA as originally enacted directed agencies to recommend legislation necessary to make their authority, rules, policies and procedures adequate to assure compliance with its requirements. ${ }^{51}$ Friends of Mammoth made it apparent that the legislature itself must devise some machinery to permit regulatory agencies to handle the additional burdens imposed on them. The amendments provide a flexible framework within which individual agencies can accomodate their needs to the statutory mandate.

Preparation of fairly detailed guidelines by a central state agency $^{52}$ should be helpful to local and other state bodies with less expertise or specific concern for environmental issues. The history of NEPA litigation demonstrates that even answering the initial question

49 CEQ Guidelines, supra note 16 , at 7724 .

503 BNA ENv. ReP., CURRENT Dev. 1068 (1973). At least one federal court has taken a different tack, reading the guideline as a requirement that there be public controversy over the nature of a project's impact, not over the project itself. Hanly v. Kleindienst, 471 F.2d 823, 830 (2d Cir. 1972), cert. denied, 93 S. Ct. 2290 (1973).

51 Cal. Stats. 1970, ch. 1433, at 2782, repealed by Cal. Stats. 1972, ch. 1154, \& 8. See CaL. Pub. REs. Code $\$ 21106$ (West Supp. 1973).

52 See notes 35-50 supra \& accompanying text. 
of whether a report should be written often requires considerable travail..$^{53}$ Without sacrificing the advantages of central administration, the amendments give agencies the right to seek changes in the guidelines in the light of experience. ${ }^{54}$

An agency preparing an impact report can seek assistance from virtually anyone with particular expertise in a relevant area. Consultation with other agencies having jurisdiction over the project is required. ${ }^{55}$ An agency may also provide for the preparation of impact reports by contract. ${ }^{56}$ Finally, an applicant for a license may be required to assist the agency by the payment of a fee, ${ }^{57}$ submission of information, or preparation of the report itself. ${ }^{58}$

Permitting agencies to seek help from the private sector in writing impact reports is desirable in the state and local context. The alternative for most government bodies would be the creation of a separate in-house staff of investigators. The practical difficulty of this approach stems from the usual fiscal considerations, as well as the shortage of personnel with the necessary training and experience. It is to be anticipated that professional consulting firms will be established in California for the sole purpose of preparing impact reports for a number of government bodies. If this proves impractical, a middle course is available for licensing procedures. Data could be elicited from applicants; interested environmental groups or the public at large could be invited to comment on the proposal. The agency's function in writing its report would then be chiefly evaluative. ${ }^{59}$

53 See City of Boston v. Volpe, 464 F.2d 254 (1st Cir. 1972); Brooks v. Volpe, 460 F.2d 1193 (9th Cir. 1972); Hanly v. Mitchell, 460 F.2d 640 (2d Cir.), cert. denied, 409 U.S. 990, after remand, Hanly v. Kleindienst, 471 F.2d 823 (2d Cir. 1972), cert. denied, 93 S. Ct. 2290 (1973) ; S.C.R.A.P. v. United States, 346 F. Supp. 189 (D.D.C. 1972), rev'd, 41 U.S.L.W. 4866 (U.S. June 18, 1973); Silva v. Romney, 342 F. Supp. 783 (D. Mass. 1972).

54 CaI. Pub. Res. Code $\S 21086$ (West Supp. 1973), amending Cal. Stats. 1970, ch. 1433.

55 Id. $\$ 21086$. The amendments deleted a provision for mandatory consultation with every agency having "special expertise;" the original language parallelled \$ 102 (2) (C) of NEPA, 42 U.S.C. $\$ 4332(2)$ (C) (1970). Such consultation is now optional, since an agency can consult with any "person," defined to include agencies.

58 Cal. Pub. Res. Code $\$ 21100$ (West Supp. 1973), amending Cal. Stats. 1970, ch. 1433 , at $2781-82$.

57 Id. $\$ 21089$, amending Cal. Stats. 1970, ch. 1433. While this provision should be used primarily for private applicants, it authorizes one agency to collect a fee from another. This would be the case if the lead agency-having principal responsibility for carrying out or approving a project, id. $\$ 21067$, was not the agency proposing the project. The cost of evaluation should reasonably be borne by the proposing party. This provision does not authorize charging a fee for interagency consultation as long as the agency seeking information is preparing the impact report.

58 Id. $\$ 21160$.

59 Because of CEQA's policy of full evaluation of environmental factors, agencies which choose not to perform fact-gathering themselves should rarely base their impact reports entirely on facts submitted by applicants.

The amendments permit agencies to compel applicants to submit an "impact report." It may be suggested that this authorizes delegation of the entire preparation function. This argument has been rejected by a federal court, Greene County Planning Bd. v. Federal Power Comm'n, 455 F.2d 412 (2d Cir.), cert. denied, 409 U.S. 849 (1972). 
Agencies thus have a number of sources of information and expertise which they can consult in order to prepare adequate impact reports, and a number of ways of using those sources. Because reports are subject to challenge for inadequacy, it is in the interest of applicants and agencies to see that all relevant environmental considerations are weighed. A finding of significant impact will not automatically bar approval of a project, so there should not be too great an incentive to submit false or inadequate reports. ${ }^{60}$

The original provision for consultation with other agencies was identical to that found in NEPA. ${ }^{01}$ Its limitation was presumably undertaken in the interest of efficiency, although there has been no indication that NEPA's requirement is placing an intolerable strain on federal agencies. Because such consultation is still an alternative under the amendment the latter may be seen as an attempt to provide greater flexibility to state agencies, more likely to suffer from shortages of resources. More serious is the continued failure of CEQA to provide for post-preparation review of impact reports by other agencies. Under section 102(2)(C) of NEPA, impact statements are circulated for comment by agencies with special expertise in the environmental issues involved in the proposed action. ${ }^{62}$ Such screening is invaluable to agencies themselves and to concerned members of the public-still primary watchdogs outside the initiating agency. ${ }^{63}$ The short statute of limitations imposed by CEQA on challenges to impact reports ${ }^{64}$ makes it doubly important that expert views be available if the public is to have a ready basis on which to seek review when it is desirable.

\section{Reviere of Administrative Actions}

The final portion of this Comment focuses on the CEQA amendments which prescribe the manner in which impact statements and related agency determinations can be reviewed. The legislature clearly

NEPA, however, contains no explicit language similar to CEQA's new $\S 21160$. Nevertheless, it can be shown that abdication of responsibility for final evaluation is improper under CEQA. The Act's declarations of legislative intent, $\$ \$ 21000-01$, demonstrate legislative concern that agencies themselves give full consideration to environmental factors. Moreover, amended $\S \S 21100,21151$ require that state and local agencies "shall prepare, or cause to be prepared by contract" an impact report (emphasis added) ; a report written by a license applicant does not fit that definition. To allow an interested party control over evaluation of a project's environmental impact would subvert the statutory purpose.

60 Extended consideration of the question whether approval of a project, after a finding of significant impact, can be set aside is beyond the scope of this Comment. See notes 75-77 infra \& accompanying text.

61 NEPA \& 102(2)(C), 42 U.S.C. § 4332(2)(C) (1970).

62 EPA has adopted streamlined procedures for reporting its evaluations. EPA, Environmental Impact Statements and Other Actions Impacting the Environment-Availability of Comments, 38 Fed. Reg. 1955 (1973).

63 Neither CEQ nor EPA has authority to seek review of agency determinations under NEPA. See NEPA § 204, 42 U.S.C. $\S 4344$ (1970); Reorganization Plan No. 3 of 1970, 35 Fed. Reg. 15623, 42 U.S.C. $\$ 4321$ n. (1970). 1433.

64 Cal. Pub. Res. Code $§ 21167$ (West Supp. 1973), amending Cal. Stats. 1970, ch. 
intended, by enacting chapter $6,^{65}$ to minimize the delay and disruption which inevitably accompany review. At the same time, the amendments ratify the courts' exercise of a certain measure of control over agency decisions pursuant to CEQA. ${ }^{66}$ Agency action may be challenged on three grounds: (1) that a project which may have a significant environmental impact is being carried out or was approved without a determination of whether an impact report should be prepared; (2) that the agency has improperly determined whether a report should be prepared; (3) that an impact report does not comply with the statute. ${ }^{67}$ These classifications cover the range of claims that an impact report should be written or modified. Specific attention is given to cases in which changed conditions--either in the project or the attendant circumstances-render a previously satisfactory report . inadequate. ${ }^{68}$

The statute of limitations for filing a challenge to an agency decision varies according to the grounds for that challenge; however, in all cases, the agency must be served before any pleading may be filed. ${ }^{69}$ When the challenge is to the adequacy of a report or to an agency's decision that an impact report is not required, a thirty-day statute of limitations ${ }^{70}$ runs from the filing of notice required of an agency stating whether or not an impact report has been prepared. ${ }^{71}$ While this period is short, it is an appropriate limitation in the regulatory area ${ }^{72} \mathrm{~A}$ successful applicant for a license or permit should not have to delay unreasonably long before he can feel free to act in reliance on it. The members of the public most likely to oppose a permit are those in the area where the project will be located, or those who are particularly concerned with that type of project. In many cases the former can be expected to be aware that an application is

65 Cax. Pub. Res. Code $\S \S 21165-74$ (West Supp. 1973), amending Cal. Stats. 1970, ch. 1433.

${ }^{66}$ See Environmental Defense Fund, Inc. v. Coastside County Water Dist., 27 Cal. App. 3d 695, 104 Cal. Rptr, 197 (1972).

67 CaL. Pub. Res. CODE $§ 21167$ (West Supp. 1973), amending Cal. Stats. 1970, ch. 1433. Even though an impact report has been prepared and is adequate, there remains a fourth ground on which a challenge might be based: that the agency's decision to approve a "project" which the report covers is not supported by substantial evidence or is arbitrary and capricious. Claims of this sort have been recognized under NEPA. Environmental Defense Fund, Inc. v. Corps of Engineers, 470 F.2d 289, 297-300 (8th Cir. 1972). Although it is not provided for in the amendments to CEQA, "substantive review" might be recognized by courts. Its importance must be assessed in light of the fact that no federal court has ever overturned an agency's decision on this rationale. 1433.

68 Cat. Pub. Res. Code $§ 21166$ (West Supp. 1973), amending Cal. Stats. 1970, ch.

69 Id. \& 21167.5 .

70 Id. § 21167 (b).

71 Id. \& 21152.

72 Similar statutes are typical of zoning ordinances. See, e.g., DEL. CODE ANN., tit. 7, $\S \S 7007,7008$ (Supp. 1972). The Delaware Coastal Zone Act, inspired by environmental concern with industrial overdevelopment in the state's coastal areas, imposes a 14-day statute of limitations on administrative appeals from licensing decisions, and a 20-day limitation on subsequent appeal to the superior court. 
pending, and the latter can safeguard their interest by keeping abreast of the public records in which the requisite notice must appear. There will undeniably be some occasions when prospective opponents are unaware of a project until after the limitation period has expired, but in view of the need for efficiency it appears that this risk is not an unreasonable one. If the statute proves overly harsh or subject to abuse, the continuing concern of the legislature should supply an appropriate amendment. ${ }^{73}$

A more liberal 180-day limitation applies to challenges based on an agency's failure to determine whether an impact report is required. ${ }^{74}$ The extension is necesary since in those cases no public notice is filed. A thirty-day limitation could easily expire before an agency decision became publicly visible, particularly if the proponent of a project chose to lie low until the period expired.

Once suit has been filed, the CEQA amendments provide that a familiar administrative law standard be applied by courts in reviewing agency decisions: the requirement of substantial evidence. ${ }^{75}$ While slightly different formulations are advanced, depending on the nature of the agency proceeding in question, it is clear that only a limited form of review-that appropriate to agency factual determinationsis contemplated. Such deference to agency findings is wholly appropriate: questions of environmental impact, which are essentially factual, will be answered by those possessing the necessary ability, and the weighing of competing considerations will be performed by the agencies primarily responsible for making policy. Thus, this is a wise provision if courts are not to sit in judgment generally over agency policy.

${ }^{73} \mathrm{An}$ outstanding example of a procedure designed to provide the widest feasible notice of impending agency action is that recently established by the New York Public Service Commission for licensing construction of large steam generating facilities. An applicant is required to serve notice on any municipality where a primary or alternate site is located; state legislators within whose districts primary and alternate sites are located; designated state agencies; and other state and federal governments with jurisdiction over all or part of a proposed facility. In addition, notice must be published once a week for 4 consecutive weeks in a newspaper or newspapers of general circulation in the areas of primary and alternate sites. This notice must include, inter alia, a brief description of the proposed site and facility; proposed primary and alternate locations; the date an application was or will be filed; a statement that under the law a facility may be approved that differs in whole or in part from the proposal; and, where practicable, the name, address and telephone number of the applicant's representative and a member of the commission's staff who may be contacted for information and assistance. Finally, notice must be directed to any person who, in the last 12 months, has filed a statement requesting notice of applications with respect to facilities in the area of a primary or alternate site. 16A OFFICIAI COMPIIATION-CODES, RULES AND REguLATIONS OF THE STATE OF NEW YORK § 70.5 (1972).

These regulations would be impractical for general adoption. They make a considerable amount of delay and expense inevitable. These are acceptable when applied to major actions likely to be highly controversial, but would prove unworkable for an agency passing on a significant volume of applications.

74 Car. Pub. Res. Code $\S 21167$ (a) (West Supp. 1973), amending Cal. Stats. 1970, ch. 1433.

75 CAL. PUB. Res. Code $\S 21168.5$ (West Supp. 1973), amending Cal. Stats. 1970, ch. 1433. This differs from NEPA under which the issue of standard of review (to be applied by courts to agency decisions) has not been uniformly resolved. See Hanly v. Kleindienst, 471 F.2d 823, 828-30, cert. denied, 93 S. Ct. 2290 (1973). 
It may be debated whether the amendments' standard of review was intended to overrule dictum in Friends of Mammoth, that "if the adverse consequences [of a project] to the environment can be mitigated, or if feasible alternatives are available, the proposed activity . . . should not be approved." ${ }^{\prime 76}$ At the very least, it now appears that the existence of one of the above factors, without more, will not cause a court automatically to reverse agency approval of a project. Emphasis is shifted to an examination of the facts supporting a decision: only if they are not "substantial" can it be overruled. On the other hand, the impact report may disclose an alternate course of action which is as desirable in all respects as the propsal, but much less destructive of the environment. In such a case, approval could be considered an abuse of discretion, unsupported by substantial evidence on the whole record. More typically, an alternative's environmental benefits will have to be measured against other weighty factors. These may include cost, feasibility, or an individual's right to make a free choice between reasonable alternatives. When balancing is required, the amendments lend their weight to a presumption of regularity in administrative choice. $^{77}$

\section{CONCLUSION}

Eleven states and Puerto Rico have adopted statutes or regulations that require the preparation of environmental impact statements. $^{78}$ Others will certainly follow. Many present statutes are patterned after NEPA; with few exceptions, they do not recognize or deal with the major problems addresed by the California legislature in the CEQA amendments. These include the scope of the impact statement requirement, both as to the types of actions covered and the environmental effects deemed significant; difficulties due to the fundamental difference between state and federal regulation; and limitations on judicial review. As long as the public is concerned with the quality of the environment, the same issues must eventually arise in other states. It would be advisable for legislatures to seize the

768 Cal. 3d at -, n.8, 500 P.2d at 1371, 104 Cal. Rptr. at 27.

77 It follows from this discussion that a proposed project with an adverse environmental effect could be approved if no feasible alternative exists. The modified guidelines proposed by the Resources Agency make this explicit, and recommend balancing of economic and environmental factors. L.A. Times, Feb. 18, 1973, § 1, at 20, col. 1. Nothing in the language or legislative history of CEQA or NEPA suggests that environmental impact should be a controlling element in every government decision.

78 Statutes include Dex. Code Ann., tit. 7, §7005(a) (Supp. 1972); Ind. Ann. Stat. § 35-5303 (Supp. 1972); Mont. Rev. Codes AnN. \& 69-6504 (Supp. 1971); N.M. Stat. ANN. \& 12-20-6 (Supp, 1971) ; N.C. Gen. Stat. \& 113A-4 (Supp. 1971) ; P.R. LAws ANn., tit. 12, § 1124 (Supp. 1972); WasH. REv. Code ANN. \& 43.21C.030 (Supp. 1972); Ass. Bill 875, 1971 Wis. Laws ch. 274. \& 2, at 1043 (published Apr. 28, 1972). Administrative requirements exist in Arizona, Game and Fish Comm'n, Procedures for Implementation of Water Conservation and Water Recreation Development (May 27, 1971), cited in CEQ, Third Annual Report on tae Environment 181 (1972); Hawaii, id. (1972); Michigan, 3 BNA Env. Rep., Current Dev. 1069 (1973); New York, 16A OfFicial CompILATION-Codes, Rules and Regulations of the STate of NEW York \& 86.5 (1970). 
present opportunity for careful study of their own statutes and rules, in the light of California's experience. Although a sizeable body of law is growing up under NEPA, states may find that they do not want the wholesale adoption of federal precedent by their courts. California has taken the lead, under pressure of court decision. It is now time for other states to emulate California's attempts to clarify vague statutory language, reexamine requirements in the light of practicality and necessity, and demonstrate continued dedication to the development of a workable system of environmental protection. 